contrast to many of the blotchy "process" illustrations now so common.

The coloured illustrations are good of their kind, but it needs the patience of a Bauer to do justice to such exquisite flowers as those of the Calochortus, and in the present instance the artist evidently prefers effect to detail.

Mr. Nicholson's article on Magnolias is likely to be of permanent value, and Mr. Carl Purdy's revision of the genus Calochortus will be useful to those who have not ready access to the more complete monograph in the Proceedings of the California Academy of Sciences.

"Sylva" is represented by an article on the Corsican pine, concerning which so much has been written of late years. Alluding to the great variation which occurs among the pines, the author of the article says that the "wild type of a forest tree is the best, and that sports are worthless." This is a statement that appears to require some modification. In the first place, it is not easy to determine what is the wild type. If we take the Corsican tree as the type, are we to abandon as worthless the black Austrian, the Pyrenean, the Calabrian, the Pallasian, and the many other varieties of the Corsican pine? But perhaps the writer does not include these as "sports." At any rate, in their several ways they are as valuable as the form arbitrarily taken as the type.

Flora and Sylva promises to be a very attractive and useful addition to garden literature.

\section{INTERACTION BETWEEN THE MENTAL AND THE MATERIAL ASPECTS OF THINGS.'}

THERE are certain ambiguous terms, to the undiscriminating use of which some misunderstandings are due. One of these is the term "science," which may be used either as synonymous with the unbiased and reverent pursuit of truth by patient and accurate methods in all departments of knowledge; or as representing the generally accepted notions of naturalists at any one epoch, together with such positive and negative tendencies and extensions into more speculative regions as may be favoured by them. The distinction between these two dissimilar things is hardly sufficiently accentuated by the use of a large or a small initial letter for the word

Another ambiguous word is "faith," which may signify intellectual credence attached to some doctrine, in which case an emphatic and militant definite article is sometimes prefixed to it; or it may denote a moral, i.e. emotional and conative attitude to the universe in general, irrespective of intellectual cognisance of specific facts.

A third is the term " prayer," which again may represent either a submissive and devotional passive attitude of the soul in presence of a higher power, or an active and energetic petition for certain benefits or privileges, and especially for aid and guidance in crises or emergencies.

And lastly, many, ambiguities, I venture to think, attach to the term "God," of which I will only mention three.

First, it may signify the highest theoretical and practica conception of men at any given epoch on this planet; a use it may mean the thriate'to the science of theologv. Second, it may mean the Ultimate and Infinite and Absolute, concerning which no human predication is possible, and of which no even initially adequate conception can be made. Third, there are signs of its coming to be used in a limited sense by certain not unphilosophic persons-whether justifiably or not-to denote a Being, a ruler, an administrator, who is striving to evolve order out of mental and moral chaos, and to bring gradually towards perfection a race such as is competent to inhabit the surface of planets; the manager, so to speak, of the process of evolution. A being infinite in comparison to ourselves, but still a being with potentiditioned ahead, and with the possibility of advance, conditioned therefore to some extent by what we are conscious
of as "time." All these.

1 iable to enter into odr

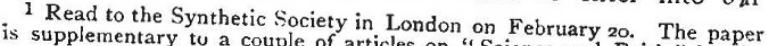
same author, in the Hibbert Journal for on "Science and Faith," by the and it states, for the purpose of discur October, 1902, and January, roo3; those articles were based. No. 1747 , VOL. 67] present discussion, which concerns, I take it, fundamentally the intercommunion and interaction between the divine and the human, chiefly in the regions of volition and of action on the physical world. The influence of the divine on the human has been variously conceived in different ages, and various forms of difficulty have been at different times felt and suggested; but always some sort of analogy between human action and divine action has had perforce to be drawn in order to make the latter in the least intelligible to our conception. The latest form of difficulty is peculiarly deep-seated, and is a natural outcome of an age of physical science. It consists in denying the possibility of guidance or of control, not only on the part of a Deity, but on the part of every one of his creatures. It consists in pressing the laws of physics to what seems their logical and ultimate conclusion, in applying the conservation of energy without ruth or hesitation, and so excluding, as it has seemed, the possibility of free-will action, of guidance, of the self-determined action of mind or living things upon matter, altogether. The appearance of control has been considered illusory, and has been replaced by a doctrine of pure mechanism, enveloping living things as well as inorganic nature.

And those who for any reason have felt disinclined or unable to acquiesce in this exclusion of non-mechanical agencies, whether it be by reason of faith and instinct, or by reason of direct experience and sensation to the contrary, have thought it necessary of late years to seek to undermine the foundations of physics, and to show that its muchvaunted laws rest upon a hollow foundation, that their exactitude is illusory, that the conservation of energy, for instance, has been too rapid an induction, that there may be ways of eluding many physical laws and of avoiding submission to their sovereign sway.

By this sacrifice it has been thought that the eliminated guidance and control can philosophically be reintroduced.

This, I gather, may have been the chief motive of an attack on physics led by an American, J. B. Stallo, in a little book called the "Concepts of Physics," which has at various times attracted some attention. But the worst of that book was that Stallo was not really familiar with the teachings of the great physicists; he appears to have collected his information from popular writings, where the doctrines were very imperfectly laid down; so that most of the book is occupied in demolishing constructions of straw, unrecognisable by professed physicists except as caricatures at which they also might be willing to heave an occasional missile.

The armoury pressed into the service of Prof. James Ward's attack is of weightier calibre, and his criticism cannot in general be ignored as based upon inadequate acquaintance with the principles under discussion; but still his Gifford lectures raise an antithesis or antagonism between the fundamental laws of mechanics and the possibility of any intervention, whether human or divine.

If this antagonism is substantial it is serious ; for natural philosophers will not be willing to concede fundamental inaccuracy or uncertainty about their recognised and longestablished laws of motion, nor will they be prepared to tolerate any the least departure from the law of the conservation of energy. Hence, if guidance and control can be admitted into the scheme by no means short of refuting or modifying those laws, there may be every expectation that the attitude of scientific men will be perennially hostile to the idea of guidance or control, and so to the efficacy of prayer, and to many another practical outcome of religious belief. It becomes therefore an important question to consider whether it is true that life or mind is incompetent to disarrange or interfere with matter at all, except as an antomatic part of the machine, or rather except as an ornarental appendage or dependent accessory of its working parts.

Now experience-the same kind of experience as gave us our scheme of mechanics-shows us that to all appearance live animals certainly can direct and control mechanical energies to bring about desired and preconceived results e.g. the Forth Bridge. Undoubtedly our body is material and can act on other matter, and its energy is derived from food, like any other self-propelled and fuel-fed mechanism; the question is whether our will or mind or life can direct our body's energy along certain channels to attain desired 
ends; or whether direction, as well as amount, of activity is wholly determined by mechanical causes.

Answers that might be given are :-

(a) That life is a form of energy, and achieves its results by imparting to matter energy that would not otherwise be in existence, in which case life is a part of the machine, and as truly mechanical as all the rest. I hold that this is false ; because the essence of energy is that it can transform itself into other forms, remaining constant in quantity, whereas life does not transmute itself into any form of energy, nor does death affect the sum of energy in any known way.

(b) That life is something outside the scheme of mechanics, although it can nevertheless touch or direct material motion, subject always to the laws of energy and all other mechanical laws; supplementing them, but contradicting or traversing them no whit.

This I hold to be true; but in order to admit its truth we must recognise that triggers can be pulled-force exerted, and energy directed-without any introduction of energy from without; in other words, that the energy of operations automatically going on in any active region of the universe -any region where transformation and transference of energy are continuously occurring, whether life be present or not-that this energy can by means of life be guided along paths that it would not automatically have taken, and can be directed so as to produce effects that would not otherwise have occurred; and this without any break or suspension of the laws of dynamics.

That is where I part company with Prof. James Ward in the second volume of "Naturalism and Agnosticism," notwithstanding that I feel sure that Mr. A. J. Balfour agrees with him.

Those who take his view must either throw overboard the possibility of interference or guidance or willed action altogether, which is one alternative, or must assume that the laws of physics are only approximate and incomplete, which is the other alternative the alternative favoured by Prof. James Ward. I wish to argue that neither of these alternatives is necessary, and that there is a third or middle course of proverbial safety.

On a stagnant and inactive world life would be admittedly powerless ; it could only make dry bones stir in such a world if itself were a form of energy; I do not suppose for a moment that it could be incarnated on such a world; it is only potent where inorganic energy is in constant process of transfer and transformation. In other words, life can generate no trace of energy, it can only guide it.

Guidance is a passive exertion of force without doing work; as a quiescent rail can guide a train to its destination, provided an active engine propels it. If a stone is rolling over a cliff, it is all the same to "energy " whether it fall on point $A$ or point $B$ of the beach. But at $A$ it shall merely dent the sand, whereas at $B$ it shall strike a detonator and explode a mine. Scribbling on a piece of paper results in a certain distribution of fluid and production of a modicum of heat; so far as energy is concerned, it is the same whether we sign Andrew Carnegie or Alexander Coppersmith, yet the one effort may land us in twelve months' imprisonment or may build a library, according to circumstances, while the other achieves no result at all. John Stuart Mill used to say that our sole power over Nature was to move things; but strictly speaking we cannot do even that; we can only arrange that things shall move each other, and can determine by suitably preconceived plans the kind and direction of the motion that shall ensue at a given time and place. Provided always that we include in this category of " things " our undoubtedly material bodies, muscles and nerves.

But here is just the puzzle; at what point does will and determination enter into the scheme? Contemplate a brain cell, whence originates a certain nerve-process whereby energy is liberated with some resultant effect; what pulled the detent in that cell which started the impulse? No doubt some chemical process, combination or dissociation, something atomic, occurred; what made it occur just then and in that way?

$I$ answer, the same sort of prearrangement that determined whether the stone from the cliff should fall on point $A$ or point $B$-the same sort of process that guided the pen to make legible and effective writing instead of illegible and ineffective scrawls - the same kind of process that determines when and where a trigger shall be pulled so as to secure the anticipated slaughter of a bird. So far as energy is concerned, the explosion and the trigger-pulling are the same identical operations, whether the aim be exact or random. It is vitality which directs; it is physical energy which is directed and controlled both in time and space.

I lay stress upon a study of the nature and mode of human action of the interfering or guiding kind, because from it we must be led if we are to form any intelligent conception of divine action. True, it might be possible to deny human agency or power and yet to admit the possibility of divine agency, though that would be a nebulous and at least inconclusive procedure; but if we are once constrained to admit the existence and reality of human guidance and control, we cannot deny the possibility of such powers and action to any higher being, nor even to any totality of things of which we are a part.

The point immediately at issue turns upon the distinction between "force" and "energy." These terms have been so popularly confused that it may be difficult always to discriminate them, but in physics they are absolutely discriminated. A force in motion is a "power," it does work and transfers energy from one body to another. But a force at rest-a mere statical stress, like that exerted by a pillar or a watershed-does no work, and alters no energy; yet the one sustains a roof which would otherwise fall, thereby screening a portion of ground from vegetation; while the other deflects a rain-drop into the Danube or the Rhine.

It will be said some energy is needed to pull a hairtrigger, to open the throttle valve of an engine, to press the button which shall shatter a rock. Granted; but the work-concomitants of that energy are all familiar, and equally present whether it be so arranged as to produce any predetermined effect or not. The opening of the throttle valve, for instance, demands just the same exertion, and results in just the same imperceptible transformation of fully-accounted-for energy, whether it be used to start a train in accordance with a time-table and the guard's whistle, or whether it be pushed over as by the wind at random. The shouting of an order to a troop demands vocal energy, and produces its due equivalent of sound; but the intelligibility of the order is something superadded, and its result may be to make not sound or heat alone, but history.

Energy is needed to perform any physical operation, but the energy is independent of the determination or arrangement. Guidance and control are not forms of energy, and their superposition upon the scheme of physics perturbs physical and mechanical laws no whit, though it may profoundly affect the consequences resulting from those same laws. The whole effort of civilisation would be futile if we could not guide the powers of nature. The powers are there, else we should be helpless; but life and mind are outside those powers, and can direct them along an organised course.

And this same life or mind, as we know it, is accessible to petition, to affection, to pity, to a multitude of nonphysical influences; and hence, indirectly, the little plot of physical universe which is now our temporary home has become amenable to truly spiritual control.

My contention, then, is that whereas life cannot generate energy, it can exert guiding force, using the term force in its accurate mechanical sense; not "power" or anything active, but purely passive, directing-perpendicular to the direction of motion; the same kind of force which can constrain a stone to revolve in a circle instead of in a straight "gine; a force like that of a groove or slot or channel or

I do not see how this action of life can be resented, except by those who deny life to be anything at all. If it exists, if it is not mere illusion, it appears to me to be something the full significance of which lies in another scheme of things, but which touches and interacts with this material universe in a certain way, building its particles into notable configurations for a time-oak, eagle, man-and then evaporating whence it came. This language is vague and figurative undoubtedly, but, I contend, appropriately so, for we have not yet a theory of life--we have not even a theory of the

No. I 747 , vOL. 67$]$ 
essential nature of gravitation; discoveries are waiting to be made in this region, and it is absurd to suppose that we are already in possession of all the data. We can wait; but meanwhile we need not pretend that because we do not understand it, therefore life is an impotent nonentity. I suggest that the philosophic attitude is to observe and recognise its effects, both what it can and what it cannot achieve, and realise that our theory of it is at present extremely partial and incomplete.

\section{Summary.}

The chief contentions are :-

(I) That the fundamental laws of physics, complete and accurate as they are, in no way exclude guidance of events by the agency of life or mind or other unknown influence.

(2) That common experience shows that living creatures do exert such guidance, and further, that they are amenable to non-material or spiritual influences from each other.

The dualistic form of this language is a necessity of expression, and inevitable for practical purposes; it is not intended to imply any ultimate or philosophic dualism. The writer finds himself unable, with his present knowledge, to use language appropriate to unification, which he regards as an aim rather than as an achievement.

Oliver J. LODGE.

\section{UNIVERSITY AND EDUCATIONAL} INTELLIGENCE.

Aт a meeting of the Senate of Dublin University on April 18, the degree of doctor in science was conferred honoris causa on Sir William Abney, K.C.B.

Aт the graduation ceremony of the University of Glasgow on Tuesday, the honorary degree of LL.D. was conferred in absentia on Sir William Gairdner, emeritus professor of medicine in the University; and the same degree was received by Sir Norman Lockyer, K.C.B. ; Dr. Thomas Oliver, professor of physiology in the University of Durham; and Mr. Philip Watts, Director of Naval Construction at the Admiralty.

AT a meeting of the governors of the North Wales University College, held on April 15, it was announced that subscriptions amounting to more than $15,000 l$. towards providing additional buildings had been promised, among the subscribers being the King and the Prince of Wales. It was also stated that the Drapers' Company had offered $600 l$., payable in three annual instalments, towards the maintenance of an electrical engineering department.

THE Technical Education Board of the London County Council is offering for competition five senior county scholarships, together with several senior exhibitions. The scholarships are of the value of $90 l$. a year, and are tenable, in ordinary circumstances, for three years at universities, university colleges, or technical institutes, whether at home or abroad. They are confined to persons who are resident within the administrative county of London, and whose parents are in receipt of an income of not more than $400 l$. a year from all sources. The scholarships are open to candidates under twenty-two years of age on June 1 , preference being given to candidates who are under nineteen years of age. No examination is held for these scholarships and exhibitions, which are awarded on consideration of the past record and future promise of the candidates. Candidates who desire to apply for the scholarships and exhibitions can obtain application forms from the secretary of the Technical Education Board, 116 St. Martin's Lane, W.C. These forms must be returned not later than Monday, May II.

Following the suggestion of the executive committee of the Nature-Study Exhibition Association, contained in their official report, that the work of the Association would in future be carried out more satisfactorily by local organisations, certain delegated members of the Middlesex Field Club and of the Selborne Society are arranging to hold this year in London a Home Counties Nature-Study Exhibition. Lord Avebury is the chairman of the committee, and already the list of patrons is very representative. The honorary secretary, Mr. W. M. Webb, will be glad to receive at 20 Hanover Square, W., donations towards the expenses of the exhibition,

NO. I 747 , VOL. 67]
THE governing body of the Royal Agricultural College, Cirencester, has decided, in consequence of the recommendation of the recent report on British forestry, to remodel and largely develop the teaching of forestry at the college in connection with the estate management branch of the curriculum. It has been resolved to create a new chair, to be entitled the chair of estate management and forestry, and to appoint thereto a special professor or lecturer who shall be required to devote all his time to the duties of the chair, and who shall have had good experience, not only of the management of woods in this country, but also of the continental system of sylviculture followed in the State and Communal forests of France and Germany.

THE Berlin correspondent of the Times states that on October $\mathrm{I}$ the courses of instruction are to be begun at the new military technical college which is to be established in Berlin. Not more than fifty officers, who must be of such an age that they will not attain the rank of captain while sectronal courses, will, in the first instance, be summoned to the capital. They will have to show a sufficient knowledge of mathematics and physics, and must produce proofs of their general military efficiency. The full course will last three years, but officers will have to satisfy the authorities at the end of each year that it is desirable that they should continue their studies. In connection with the military subjects of the courses of instruction, lectures will be given on mathematics, physics, mechanics, electricity, chemistry, metallurgy, and surveying.

THE Senate of the University of London has approved the following scheme of courses in advanced botany, extending over the years $1903-6$, drawn up by the Board of Studies in Botany. The general idea is that each course should deal with a definite branch of botanical knowledge or with the more general aspects of the science, and should extend to about ten lectures:-1903-1904-The plant in relation to the soil, Mr. A. D. Hall; the Lycopsida, Dr. D. H. Scott, F.R.S.; the metabolic processes of plants, Prof. J. Reynolds Green, F.R.S. 1904-1905-Botany and its present problems, Sir William Thiselton-Dyer, F.R.S.; the Ascomycetes, with especial reference to the typical fructifications, Mr. V. H. Blackman; respiration, Prof. J. B. Farmer, F.R.S.; the Tubifloræ, Dr. A. B. Rendle. I9051906-Gymnosperms, Prof. F. W. Oliver; the British flora in its ecological relations, Mr. A. G. Tansley; Bryophytes, Prof. J. B. Farmer, F.R.S.

REPRESENTATIVES from the principal universities and colleges of New York State recently met at Columbia University to determine the basis upon which the award of the two Rhodes scholarships for New York State should be made. It was decided, says Science, to entrust the administration and award of the scholarships to a committee of three, to be elected by the heads of the colleges for men. The committee will consist of President Butler, President Schurman, and Chancellor Day. The conference decided that the conditions regulating the award shall be as follows:- The candidates for the scholarships to be eligible shall have satisfactorily completed the work of at least two years in some college of liberal arts and sciences in the State. Except in extraordinary circumstances, the upper age limit shall be twenty-four years at the time of entering upon the scholarship at Oxford. To be eligible, the candidate shall be a citizen of the United States and unmarried.

\section{SCIENTIFIC SERIAL.}

Journal of Botany, April.-Two brief notes by $\mathrm{Mr}$. G. West and Mr. J. Cryer refer to a Polygala identified as amarella, Crantz, which was collected on the Great Scar Limestone near Grassington.-For the East Riding of Yorkshire Mr. W. Ingham publishes a list of mosses and hepatics.-A new fossil fungus, a species of Cercosporites, is described and figured by Mr. E. S. Salmon. It was obtained from the "disodile" beds in Sicily.-Mr. S. Moore, in the identification of some plants, chiefly Compositæ, from the Transvaal, Griqualand West and British East Africa, has found several new species, for which descriptions are given.-Mr. E. S. Linton supplies a list of " Kent Rubi," and Mr. W. G. Smith has a note on a new species of Collybia. 